\title{
Antimycotic activity of ethanolic and aqueous leaf extracts of Ajuga bracteosa Wall. ex Benth. (Lamiale: Lamiaceae) and Iris kashmiriana Baker (Asparagales: Iridaceae) against some vegetable rot fungi
}

\section{Jahangir Abdullah Koka1,*, Abdul Hamid Wani ${ }^{1}$, Mohd Yaqub Bhat $^{1}$, Tariq Ahmad Wani ${ }^{2}$ and Shazia Parveen ${ }^{1}$}

${ }^{1}$ Section of Mycology and Plant Pathology. Department of Botany. University of Kashmir. Srinagar. India.

${ }^{2}$ Govt Degree College Sopore. Baramulla J and K. India.

\begin{abstract}
Antifungal activities of different solvent extracts of Ajuga bracteosa Wall. ex Benth. (Lamiale: Lamiaceae) and Iris kashmiriana Baker (Asparagales: Iridaceae) were carried out through agar well diffusion assay at three concentrations $(25 \mu \mathrm{L}$, $50 \mu \mathrm{L}$ and $75 \mu \mathrm{L}$ ) against seven rot causing fungi, viz. Penicillium expansum, Aspergillus niger, Mucor plumbeus, Alternaria alternata, Penicillium chrysogenum, Trichothecium roseum and Rhizoctonia solani. All the concentration of plant extracts showed antimycotic activity against tested pathogenic fungi. Antimycotic activity increased with the increased concentrations of plant extracts. However, higher concentrations proved more effective than lower concentrations. It was revealed from the present study that the ethanolic extract of Ajuga bracteosa showed maximum antimycotic activity against Mucor plumbeus and Rhizoctonia solani and least activity against Penicillium chrysogenum. However, the aqueous extract of Ajuga bracteosa showed maximum antifungal activity against Rhizoctonia solani and Penicillium expansum and least activity against Trichothecium roseum. It was further revealed from the present study that the ethanolic extract of Iris kashmiriana showed maximum antimycotic activity against Aspergillus niger and least activity against Rhizoctonia solani. Whereas the aqueous extract of Iris kashmiriana showed maximum antimycotic activity against Penicillium expansum and Rhizoctonia solani and least activity against Aspergillus niger.
\end{abstract}

Keywords: Antimycotic assay; Pathogenic fungi; Concentration; Plant extracts; Agar well diffusion.
Received

March 16, 2018

Accepted

April 22, 2018

Released

April 30, 2018

Full Text Article

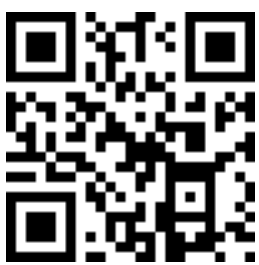

ORCID

(ㄱ) 0000-0003-0040-1624 Jahangir Abdullah Koka

(D) 0000-0002-6157-9656 Abdul Hamid Wani

(D) 0000-0002-0582-4813 Mohd Yaqub Bhat

() 0000-0002-0631-7610 Tariq Ahmad Wani

(D) 0000-0002-0086-2685 Shazia Parveen 


\section{Introduction}

Plant pathogenic fungi are known to cause huge losses to the crop plants and their produce in storage. Several control strategies have been employed by agricultural scientists to minimize the losses caused by pathogenic fungi. In this study, the important medicinal plants Ajuga bracteosa Wall. ex Benth. (Lamiale: Lamiaceae) and Iris kashmiriana Baker (Asparagales: Iridaceae) have been evaluated for their antimycotic activity.

Medicinal plants constitute the basis of primary health care for many people in Asia and are also a source of income for rural populations. Bioactive compounds currently extracted from these plants are used as pharmaceuticals, agrochemicals, flavour and fragrance ingredients, food additives and pesticides. Ajuga bracteosa is an important medicinal plant commonly known as "bungle" in English and "Jan-iadam" in Kashmiri. Ajuga bracteosa has great medicinal and economic importance (Kayani et al., 2016). In North area of India, Ajuga bracteosa is given in the treatment of fevers, neuro diseases (Nisar et al., 2014). The leaves are diuretic, stimulant and used as a substitute for cinchona (Chopra et al., 1956) the plant is also reported to possess cardio stimulant action in animals and anticancer activity in rats and mice (Dhar et al., 1968).

Iris kashmiriana is one of an important member of this Family Iridaceae, locally known as "Mazarmund" in Kashmir. The plant has been widely used in traditional medicine and modern clinical preparations to treat cold, flu, malaria, toothache, cancer, bacterial and viral infections and bruise (Hanawa et al., 1991). The phytochemical analyses of the different extracts of Iris kashmiriana have revealed the presence of different compounds including flavonoids, isoflavonoids, glycosides and tannins (Wani et al., 2012). The medicinal importance of the plant prompted isolation of a variety of pharmacologically active compounds including quinones, triterpenoids, flavonoids, isoflavonoids and stilbene glycosides (Amin et al., 2013).

Keeping in view the medicinal importance of plants, study was carried out to evaluate the antifungal activities of ethanolic and aqueous extracts of leaves of Ajuga bracteosa and Iris kashmiriana against some selected fungi causing decaying of vegetables.

\section{Materials and methods}

\section{identification \\ Plant collection and}

The fresh plant material of Ajuga bracteosa and Iris kashmiriana was collected from District Baramulla and Pulwama of Kashmir Valley. The authenticity of the plant was confirmed in Plant Taxonomy Department of Botany University of Kashmir. Adequate amount of the leaves of these plants were collected in polythene bags, brought to laboratory for evaluating their antimycotic activity under in vitro conditions.

\section{Preparation of plant extracts}

These plant leaves in a required quantity were sundried for $24 \mathrm{~h}$ and then milled into powder using morter and pestle. About $20 \mathrm{~g}$ of coarsely powdered leaves $(20 \mathrm{~g} / 100 \mathrm{~mL})$ were extracted separately in a soxhlet extractor for 8 to $10 \mathrm{~h} \quad\left(30^{\circ} \mathrm{C}-50^{\circ} \mathrm{C}\right)$ sequentially with ethanol and water separately in order to extract non-polar and polar compounds (Elgorashi et al., 2004).

\section{fungi}

Preparation of inoculums of

Pure fungal cultures of Penicillium expansum, Aspergillus niger, Alternaria alternata, Mucor plumbeus, Penicillium chrysogenum, Trichothecium roseum and Rhizoctonia solani were obtained from Plant Pathology and Mycology Laboratory, Department of 
Botany University of Kashmir. These pure cultures were grown on Potato dextrose agar (PDA) medium at $27{ }^{\circ} \mathrm{C} \pm$ $1^{\circ} \mathrm{C}$ in Petri plates. Spores of the each fungal species were collected from these cultures after 7 days (Broekaert et al., 1990). The density of spore suspension was measured and was adjusted to $2 \times 10^{5}$ CFU/mL spores (Abril et al., 2008).

\section{Antifungal activity}

Antifungal activity of ethanolic and aqueous extracts was performed by agar well diffusion method (Alzoreky et al., 2003; Ahmad et al., 2012). $100 \mu \mathrm{L}$ of standardized inoculum of each test fungi were inoculated onto sterile molten Sabouraud Dextrose Agar homogenised and poured into a sterile Petri plate to yield a uniform depth of $5 \mathrm{~mm}$. The Petri plates were allowed to solidify inside the laminar airflow chamber. Sterile cork borers of $5 \mathrm{~mm}$ in diameter were used to make three wells at periphery of each Petri plate. Different concentrations (25 $\mu \mathrm{L}, 50 \mu \mathrm{L}$ and $75 \mu \mathrm{L}$ ) of each plant extract, prepared in respective solvents were loaded into three different peripheral wells. Flucanazole solution (20 $\mu \mathrm{L} /$ well) was used as control in the separate well in the same Petri plate. The plates were then incubated at $26^{\circ} \mathrm{C} \pm$ $2{ }^{\circ} \mathrm{C}$ for 24 to $36 \mathrm{~h}$. After incubation period, the plates were observed for the zones of inhibition. Antifungal potential was evaluated by measuring inhibition zone diameters in millimeters ( $\mathrm{mm}$ ) with the help of standard measuring scale.

\section{Results}

It was observed from the results (Table 1, Figure 1) that the ethanolic extract of Ajuga bracteosa showed maximum inhibition in the fungal growth of Mucor plumbeus and Rhizoctonia solani with zone of inhibition as $20.33 \mathrm{~mm} \pm$ $0.57 \mathrm{~mm}, 22.00 \mathrm{~mm} \pm 1.00 \mathrm{~mm}, 24.66$ $\mathrm{mm} \pm 0.57 \mathrm{~mm}$ and $20.33 \mathrm{~mm} \pm 0.57 \mathrm{~mm}$, $22.33 \mathrm{~mm} \pm 0.57 \mathrm{~mm}, 24.00 \mathrm{~mm} \pm 1.00$ $\mathrm{mm}$ at $25 \mu \mathrm{L}, 50 \mu \mathrm{L}$ and $75 \mu \mathrm{L}$, respectively. Whereas as moderate inhibitory activity of Ajuga bracteosa was shown against Aspergillus niger, and Trichothecium roseum with the zone of inhibition of $19.00 \mathrm{~mm} \pm 1.00 \mathrm{~mm}, 21.66$ $\mathrm{mm} \pm 0.57 \mathrm{~mm}, 23.00 \mathrm{~mm} \pm 1.00 \mathrm{~mm}$ and $17.66 \mathrm{~mm} \pm 0.57 \mathrm{~mm}, 20.00 \mathrm{~mm} \pm$ $1.00 \mathrm{~mm}, 21.66 \mathrm{~mm} \pm 1.52 \mathrm{~mm}$ at $25 \mu \mathrm{L}$, $50 \mu \mathrm{L}$, and $75 \mu \mathrm{L}$ concentration, respectively. The inhibition in zone of fungal growth due to ethanolic extract of Ajuga bracteosa against Penicillium expansum and Alternaria alternata was $16.00 \mathrm{~mm} \pm 1.00 \mathrm{~mm}, 18.66 \mathrm{~mm} \pm 0.57$ $\mathrm{mm}, 21.00 \mathrm{~mm} \pm 1.00 \mathrm{~mm}$, and $16.00 \mathrm{~mm}$ $\pm 1.00 \mathrm{~mm}, 18.00 \mathrm{~mm} \pm 1.00 \mathrm{~mm}, 20.66$ $\mathrm{mm} \pm 0.57 \mathrm{~mm}$ at $25 \mu \mathrm{L}, 50 \mu \mathrm{L}$, and $75 \mu \mathrm{L}$ concentration, respectively. The results were compared with solution of flucanazole as a positive control. Ethanolic extract of Ajuga bracteosa showed least inhibition in fungal growth of Penicillium chrysogenum which was found as $15.66 \mathrm{~mm} \pm 0.57 \mathrm{~mm}$,

Table 1. Antifungal activity of ethanolic leaf extracts of Ajuga bracteosa.

\begin{tabular}{|l|c|c|c|c|}
\hline \multirow{2}{*}{} & \multicolumn{4}{|c|}{ Zone of Inhibition (mm) } \\
\cline { 2 - 5 } & $\mathbf{2 5} \boldsymbol{\mu L}$ & $\mathbf{5 0} \boldsymbol{\mu L}$ & $\mathbf{7 5} \boldsymbol{\mu L}$ & Control \\
\hline Penicillium expansum & $16.00 \pm 1.00$ & $18.66 \pm 0.57$ & $21.00 \pm 1.00$ & $22.00 \pm 1.00$ \\
\hline Aspergillus niger & $19.00 \pm 1.00$ & $21.66 \pm 0.57$ & $23.00 \pm 1.00$ & $24.00 \pm 1.00$ \\
\hline Alternaria alternata & $16.00 \pm 1.00$ & $18.00 \pm 1.00$ & $20.66 \pm 0.57$ & $21.66 \pm 0.57$ \\
\hline Mucor plumbeus & $20.33 \pm 0.57$ & $22.00 \pm 1.00$ & $24.66 \pm 0.57$ & $25.00 \pm 1.00$ \\
\hline Penicillium chrysogenum & $15.66 \pm 0.57$ & $18.00 \pm 1.00$ & $20.66 \pm 0.57$ & $21.00 \pm 1.00$ \\
\hline Trichothecium roseum & $17.66 \pm 0.57$ & $20.00 \pm 1.00$ & $21.66 \pm 1.52$ & $23.33 \pm 1.52$ \\
\hline Rhizoctonia solani & $20.33 \pm 0.57$ & $22.33 \pm 0.57$ & $24.00 \pm 1.00$ & $25.00 \pm 1.00$ \\
\hline
\end{tabular}

Values were performed in triplicates and represented as mean \pm SD.

Mean values followed by different superscript in a column are significantly different $(\mathrm{p} \leq 0.05)$. 


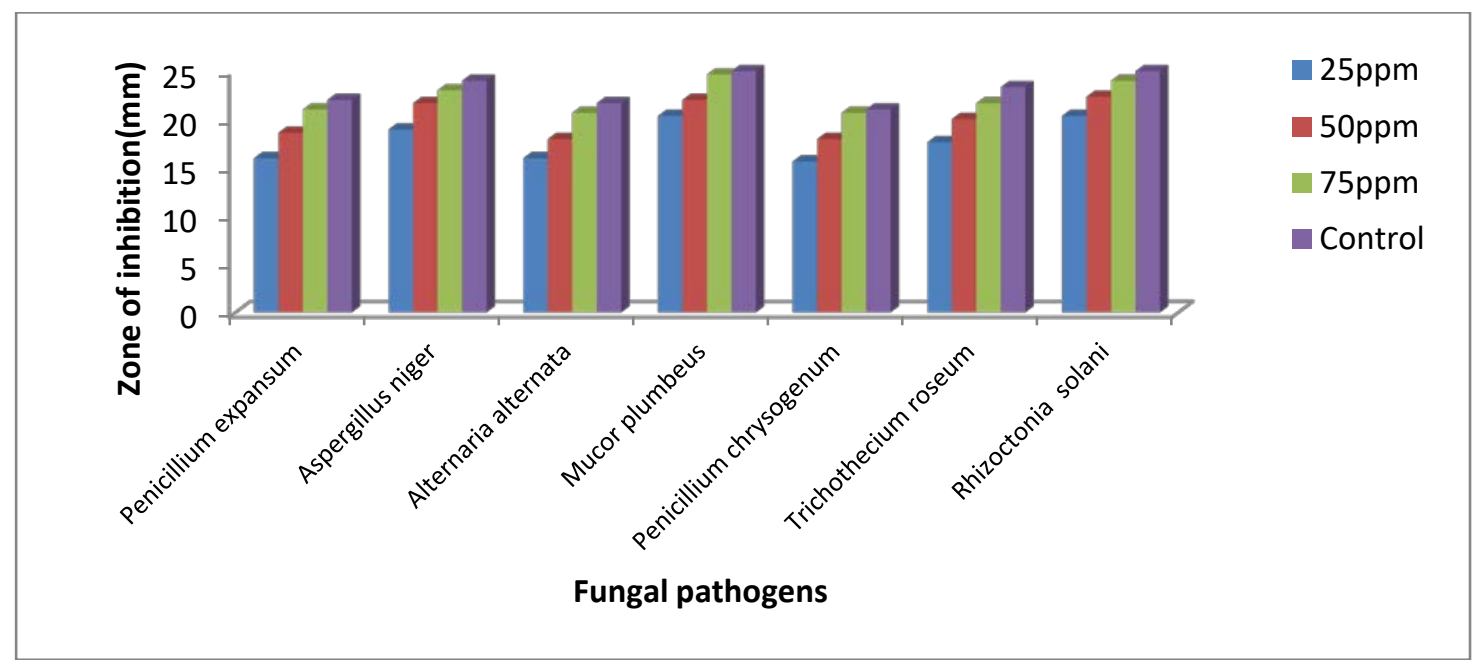

Figure 1. Antifungal activity of ethanolic leaf extracts of Ajuga bracteosa.

$18.00 \mathrm{~mm} \pm 1.00 \mathrm{~mm}$ and $20.66 \mathrm{~mm} \pm$ $0.57 \mathrm{~mm}$ at $25 \mu \mathrm{L}, 50 \mu \mathrm{L}$ and $75 \mu \mathrm{L}$ concentrations, respectively.

The aqueous extract of Ajuga bracteosa caused maximum inhibition in fungal growth at $25 \mu \mathrm{L}, 50 \mu \mathrm{L}$ and $75 \mu \mathrm{L}$ with zone of inhibition as $20.66 \mathrm{~mm} \pm$ $0.57 \mathrm{~mm}, 21.33 \mathrm{~mm} \pm 1.52 \mathrm{~mm}, 23.66$ $\mathrm{mm} \pm 1.52 \mathrm{~mm}$ and $20.33 \mathrm{~mm} \pm 0.57$ $\mathrm{mm}, 23.33 \mathrm{~mm} \pm 1.52 \mathrm{~mm}, 26.00 \mathrm{~mm}$ $\pm 1.00 \mathrm{~mm}$ against Rhizoctonia solani and Penicillium expansum, respectively. Moderate antifungal activity was recorded against Aspergillus niger and Mucor plumbeus with zone of inhibition as $20.00 \mathrm{~mm} \pm 1.00 \mathrm{~mm}, 21.66 \mathrm{~mm} \pm$ $1.52 \mathrm{~mm}, 22.33 \mathrm{~mm} \pm 1.52 \mathrm{~mm}$ and 19.00 $\mathrm{mm} \pm 1.00 \mathrm{~mm}, 21.33 \mathrm{~mm} \pm 0.57 \mathrm{~mm}$,
$22.66 \mathrm{~mm} \pm 1.52 \mathrm{~mm}$ at $25 \mu \mathrm{L}, 50 \mu \mathrm{L}$ and $75 \mu \mathrm{L}$ concentration of plant extracts, respectively. The inhibition in fungal growth of Alternaria alternata and Penicillium chrysogenum was $18.33 \mathrm{~mm} \pm$ $0.57 \mathrm{~mm}, 20.00 \mathrm{~mm} \pm 1.00 \mathrm{~mm}, 22.66$ $\mathrm{mm} \pm 1.52 \mathrm{~mm}$ and $17.00 \mathrm{~mm} \pm 1.00$ $\mathrm{mm}, 18.66 \mathrm{~mm} \pm 1.15 \mathrm{~mm}, 20.33 \mathrm{~mm} \pm$ $0.57 \mathrm{~mm}$ at $25 \mu \mathrm{L}, 50 \mu \mathrm{L}$ and $75 \mu \mathrm{L}$ concentrations of plant extracts, respectively. The zone of inhibition in mycelia of Trichothecium roseum was $15.00 \mathrm{~mm} \pm 1.00 \mathrm{~mm}, 16.66 \mathrm{~mm} \pm 1.52$ $\mathrm{mm}$ and $20.00 \mathrm{~mm} \pm 1.00 \mathrm{~mm}$, respectively at $25 \mu \mathrm{L}, 50 \mu \mathrm{L}$ and $75 \mu \mathrm{L}$ concentration of plant extract of Ajuga bracteosa (Table 2, Figure 2).

Table 2. Antifungal activity of aqueous leaf extracts of Ajuga bracteosa.

\begin{tabular}{|l|c|c|c|c|}
\hline \multirow{2}{*}{} & \multicolumn{4}{|c|}{ Zone of Inhibition (mm) } \\
\cline { 2 - 5 } & $\mathbf{2 5} \boldsymbol{\mu L}$ & $\mathbf{5 0} \boldsymbol{\mu L}$ & $\mathbf{7 5} \boldsymbol{\mu L}$ & Control \\
\hline Penicillium expansum & $20.33 \pm 0.57$ & $23.33 \pm 1.52$ & $26.00 \pm 1.00$ & $27.00 \pm 1.00$ \\
\hline Aspergillus niger & $20.00 \pm 1.00$ & $21.66 \pm 1.52$ & $22.33 \pm 1.52$ & $23.33 \pm 1.52$ \\
\hline Alternaria alternata & $18.33 \pm 0.57$ & $20.00 \pm 1.00$ & $22.66 \pm 1.52$ & $23.66 \pm 1.52$ \\
\hline Mucor plumbeus & $19.00 \pm 1.00$ & $21.33 \pm 0.57$ & $22.66 \pm 1.52$ & $24.00 \pm 1.00$ \\
\hline Penicillium chrysogenum & $17.00 \pm 1.00$ & $18.66 \pm 1.15$ & $20.33 \pm 0.57$ & $22.00 \pm 1.00$ \\
\hline Trichothecium roseum & $15.00 \pm 1.00$ & $16.66 \pm 1.52$ & $20.00 \pm 1.00$ & $22.00 \pm 1.00$ \\
\hline Rhizoctonia solani & $20.66 \pm 0.57$ & $21.33 \pm 1.52$ & $23.66 \pm 1.52$ & $26.00 \pm 1.00$ \\
\hline
\end{tabular}

Values were performed in triplicates and represented as mean \pm SD.

Mean values followed by different superscript in a column are significantly different $(p \leq 0.05)$. 


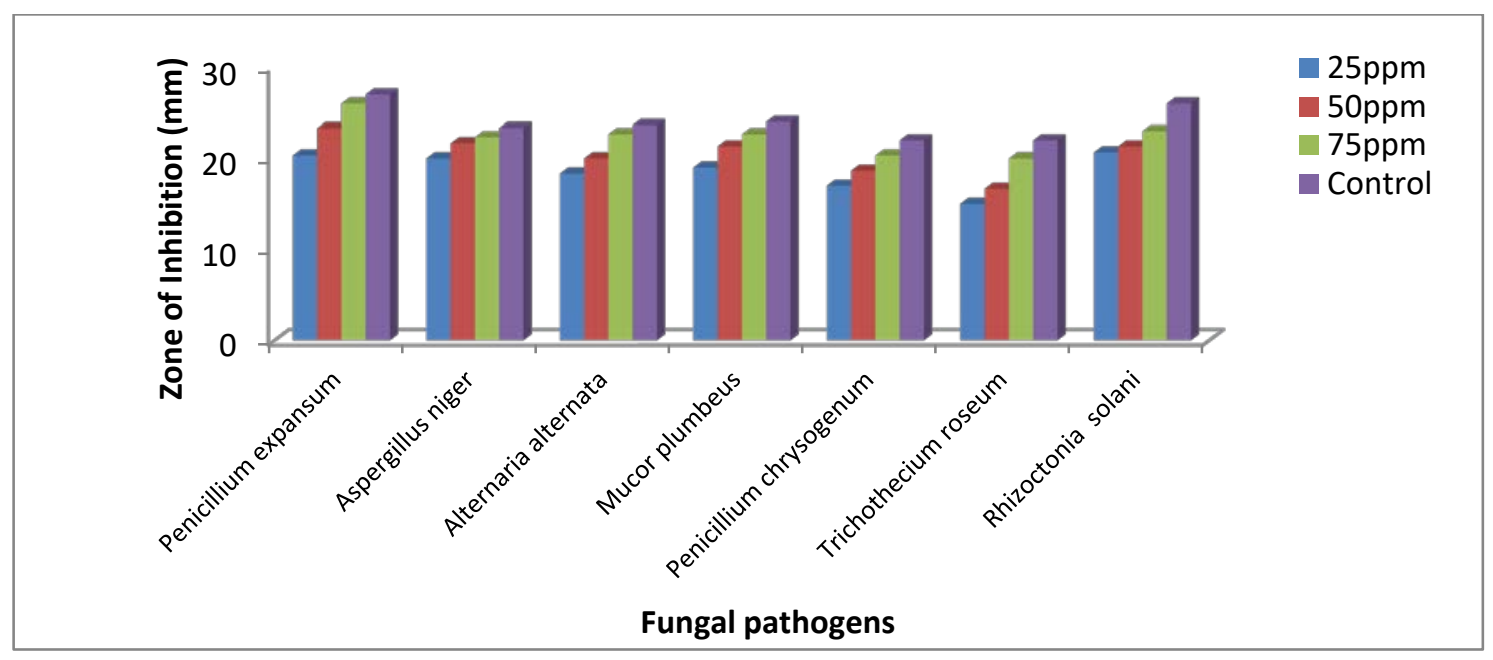

Figure 2. Antifungal activity of aqueous leaf extracts of Ajuga bracteosa.

It was revealed from the results (Table 3, Figure 3) that the ethanolic extract of Iris kashmiriana caused maximum inhibition in mycelial growth of Aspergillus niger with zone of inhibition of $20.33 \mathrm{~mm} \pm 0.57 \mathrm{~mm}, 22.00$ $\mathrm{mm} \pm 1.00 \mathrm{~mm}$ and $24.33 \mathrm{~mm} \pm 0.57 \mathrm{~mm}$ at $25 \mu \mathrm{L}, 50 \mu \mathrm{L}$ and $75 \mu \mathrm{L}$ concentrations, respectively. The zone of inhibition in case of Penicillium expansum and Mucor plumbeus was $18.66 \mathrm{~mm} \pm 0.57 \mathrm{~mm}$, $20.00 \mathrm{~mm} \pm 1.00 \mathrm{~mm}, 22.00 \mathrm{~mm} \pm 1.00$ $\mathrm{mm}$, and $18.00 \mathrm{~mm} \pm 1.00 \mathrm{~mm}, 20.00 \mathrm{~mm}$ $\pm 1.00 \mathrm{~mm}, 21.33 \mathrm{~mm} \pm 0.57 \mathrm{~mm}$ at 25 $\mu \mathrm{L}, 50 \mu \mathrm{L}$ and $75 \mu \mathrm{L}$ concentrations of Iris kashmiriana, respectively. The zone of mycelial inhibition was $17.33 \mathrm{~mm} \pm 1.15$ $\mathrm{mm}, 18.66 \mathrm{~mm} \pm 0.57 \mathrm{~mm}, 21.00 \mathrm{~mm} \pm$ $1.00 \mathrm{~mm}$ at $25 \mu \mathrm{L}, 50 \mu \mathrm{L}$ and $75 \mu \mathrm{L}$ concentrations of Iris kashmiriana against Penicillium chrysogenum. Moderate inhibitory effect of ethanolic extract was shown against Trichothecium roseum and Alternaria alternata with the zone of inhibition as $16.66 \mathrm{~mm} \pm 1.52$ $\mathrm{mm}, 18.00 \mathrm{~mm} \pm 1.00 \mathrm{~mm}, 20.33 \mathrm{~mm} \pm$ $0.57 \mathrm{~mm}$ and $16.00 \mathrm{~mm} \pm 1.00 \mathrm{~mm}, 17.66$ $\mathrm{mm} \pm 0.57 \mathrm{~mm}, 20.00 \mathrm{~mm} \pm 1.00 \mathrm{~mm}$ at $25 \mu \mathrm{L}, 50 \mu \mathrm{L}$ and $75 \mu \mathrm{L}$ concentrations of plant extract of Iris kashmiriana, respectively. Whereas, ethanolic extract of Iris kashmiriana caused least inhibition in fungal growth of Rhizoctonia solani as it varies from 13.33 $\mathrm{mm} \pm 0.57 \mathrm{~mm}, 16.00 \mathrm{~mm} \pm 1.00 \mathrm{~mm}$, and $17.33 \mathrm{~mm} \pm 0.57 \mathrm{~mm}$ at $25 \mu \mathrm{L}, 50 \mu \mathrm{L}$ and $75 \mu \mathrm{L}$ concentrations.

Table 3. Antifungal activity of ethanolic leaf extracts of Iris kashmiriana.

\begin{tabular}{|l|c|c|c|c|}
\hline \multirow{2}{*}{} & \multicolumn{4}{|c|}{ Zone of Inhibition (mm) } \\
\cline { 2 - 5 } & $\mathbf{2 5} \boldsymbol{\mu L}$ & $\mathbf{5 0} \boldsymbol{\mu L}$ & $\mathbf{7 5} \boldsymbol{\mu L}$ & Control \\
\hline Penicillium expansum & $18.66 \pm 0.57$ & $20.00 \pm 1.00$ & $22.00 \pm 1.00$ & $23.00 \pm 1.00$ \\
\hline Aspergillus niger & $20.33 \pm 0.57$ & $22.00 \pm 1.00$ & $24.33 \pm 0.57$ & $26.00 \pm 1.00$ \\
\hline Alternaria alternate & $16.00 \pm 1.00$ & $17.66 \pm 0.57$ & $20.00 \pm 1.00$ & $20.66 \pm 0.57$ \\
\hline Mucor plumbeus & $18.00 \pm 1.00$ & $20.00 \pm 1.00$ & $21.33 \pm 0.57$ & $23.33 \pm 0.57$ \\
\hline Penicillium chrysogenum & $17.33 \pm 1.15$ & $18.66 \pm 0.57$ & $21.00 \pm 1.00$ & $23.00 \pm 1.00$ \\
\hline Trichothecium roseum & $16.66 \pm 1.52$ & $18.00 \pm 1.00$ & $20.33 \pm 0.57$ & $21.00 \pm 1.00$ \\
\hline Rhizoctonia solani & $13.33 \pm 0.57$ & $16.00 \pm 1.00$ & $17.33 \pm 0.57$ & $18.33 \pm 0.57$ \\
\hline
\end{tabular}

Values were performed in triplicates and represented as mean \pm SD.

Mean values followed by different superscript in a column are significantly different $(\mathrm{p} \leq 0.05)$. 


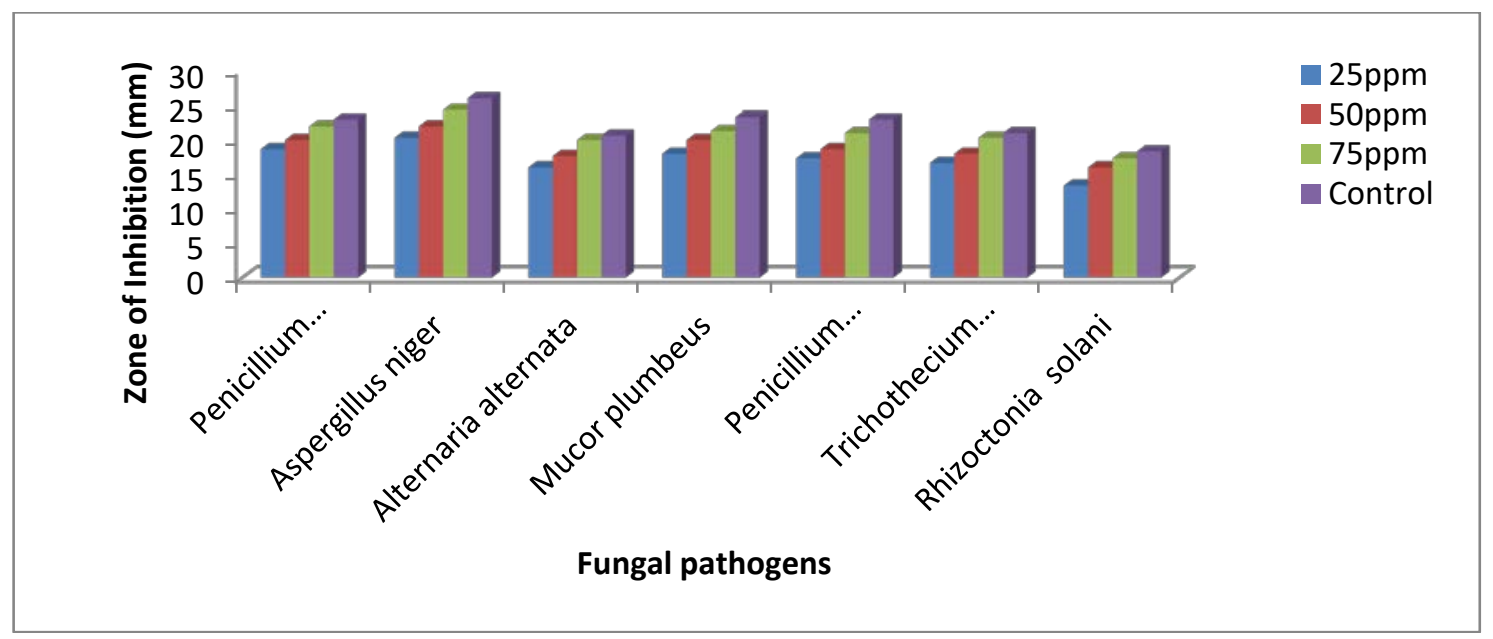

Figure 3. Antifungal activity of ethanolic leaf extracts of Iris kashmiriana.

The aqueous extract of Iris kashmiriana showed maximum antimycotic activity at $25 \mu \mathrm{L}, 50 \mu \mathrm{L}$ and $75 \mu \mathrm{L}$ concentration against Penicillium expansum and Rhizoctonia solani with the zone of inhibition of $20.66 \mathrm{~mm} \pm 1.15 \mathrm{~mm}, 22.00 \mathrm{~mm} \pm 1.00 \mathrm{~mm}, 23.00 \mathrm{~mm} \pm 1.00$ $\mathrm{mm}$ and $20.00 \mathrm{~mm} \pm 1.00 \mathrm{~mm}, 21.66 \mathrm{~mm} \pm 1.52 \mathrm{~mm}, 22.66 \mathrm{~mm} \pm 1.52 \mathrm{~mm}$, respectively. The moderate antifungal activity was observed against Mucor plumbeus and Trichothecium roseum with the zone of inhibition of $19.66 \mathrm{~mm} \pm 0.57 \mathrm{~mm}, 21.00 \mathrm{~mm} \pm 1.00 \mathrm{~mm}, 23.33$ $\mathrm{mm} \pm 0.57 \mathrm{~mm}$, and $19.33 \mathrm{~mm} \pm 0.57 \mathrm{~mm}, 23.00 \mathrm{~mm} \pm 1.00,24.33 \mathrm{~mm} \pm 0.57 \mathrm{~mm}$ at $25 \mu \mathrm{L}$, $50 \mu \mathrm{L}$ and $75 \mu \mathrm{L}$ concentrations of Iris kashmiriana, respectively. The inhibition in fungal growth of Alternaria alternata and Penicillium chrysogenum was $18.33 \mathrm{~mm} \pm 0.57 \mathrm{~mm}$, $20.00 \mathrm{~mm} \pm 1.00 \mathrm{~mm}$ and $22.00 \mathrm{~mm} \pm 1.00 \mathrm{~mm}$, and $18.00 \mathrm{~mm} \pm 1.00 \mathrm{~mm}, 20.66 \mathrm{~mm} \pm$ $0.57 \mathrm{~mm}$, and $22.66 \mathrm{~mm} \pm 0.57 \mathrm{~mm}$ at $25 \mu \mathrm{L}, 50 \mu \mathrm{L}$ and $75 \mu \mathrm{L}$ concentrations of plant extracts, respectively. The fungal growth of Aspergillus niger showed least inhibitory activity with the zone of inhibition of $18.00 \mathrm{~mm} \pm 1.00 \mathrm{~mm}, 19.33 \mathrm{~mm} \pm 0.57 \mathrm{~mm}, 22.00$ $\mathrm{mm} \pm 1.00 \mathrm{~mm}$ at $25 \mu \mathrm{L}, 50 \mu \mathrm{L}$ and $75 \mu \mathrm{L}$ concentrations of plant extract of Iris kashmiriana, respectively (Table 4, Figure 4).

Table 4. Antifungal activity of aqueous leaf extracts of Iris kashmiriana.

\begin{tabular}{|l|c|c|c|c|}
\hline \multirow{2}{*}{} & \multicolumn{4}{|c|}{ Zone of Inhibition (mm) } \\
\cline { 2 - 5 } & $\mathbf{2 5} \boldsymbol{\mu L}$ & $\mathbf{5 0} \boldsymbol{\mu L}$ & $\mathbf{7 5} \boldsymbol{\mu L}$ & Control \\
\hline Penicillium expansum & $20.66 \pm 1.15$ & $22.00 \pm 1.00$ & $23.00 \pm 1.00$ & $24.66 \pm 0.57$ \\
\hline Aspergillus niger & $18.00 \pm 1.00$ & $19.33 \pm 0.57$ & $22.00 \pm 1.00$ & $24.66 \pm 0.57$ \\
\hline Alternaria alternata & $18.33 \pm 0.57$ & $20.00 \pm 1.00$ & $22.00 \pm 1.00$ & $24.00 \pm 1.00$ \\
\hline Mucor plumbeus & $19.66 \pm 0.57$ & $21.00 \pm 1.00$ & $23.33 \pm 0.57$ & $25.00 \pm 1.00$ \\
\hline Penicillium chrysogenum & $18.00 \pm 1.00$ & $20.66 \pm 0.57$ & $22.66 \pm 0.57$ & $25.00 \pm 1.00$ \\
\hline Trichothecium roseum & $19.33 \pm 0.57$ & $23.00 \pm 1.00$ & $24.33 \pm 0.57$ & $26.00 \pm 1.00$ \\
\hline Rhizoctonia solani & $20.00 \pm 1.00$ & $21.66 \pm 1.52$ & $22.66 \pm 1.52$ & $24.00 \pm 1.00$ \\
\hline
\end{tabular}

Values were performed in triplicates and represented as mean \pm SD.

Mean values followed by different superscript in a column are significantly different $(\mathrm{p} \leq 0.05)$. 


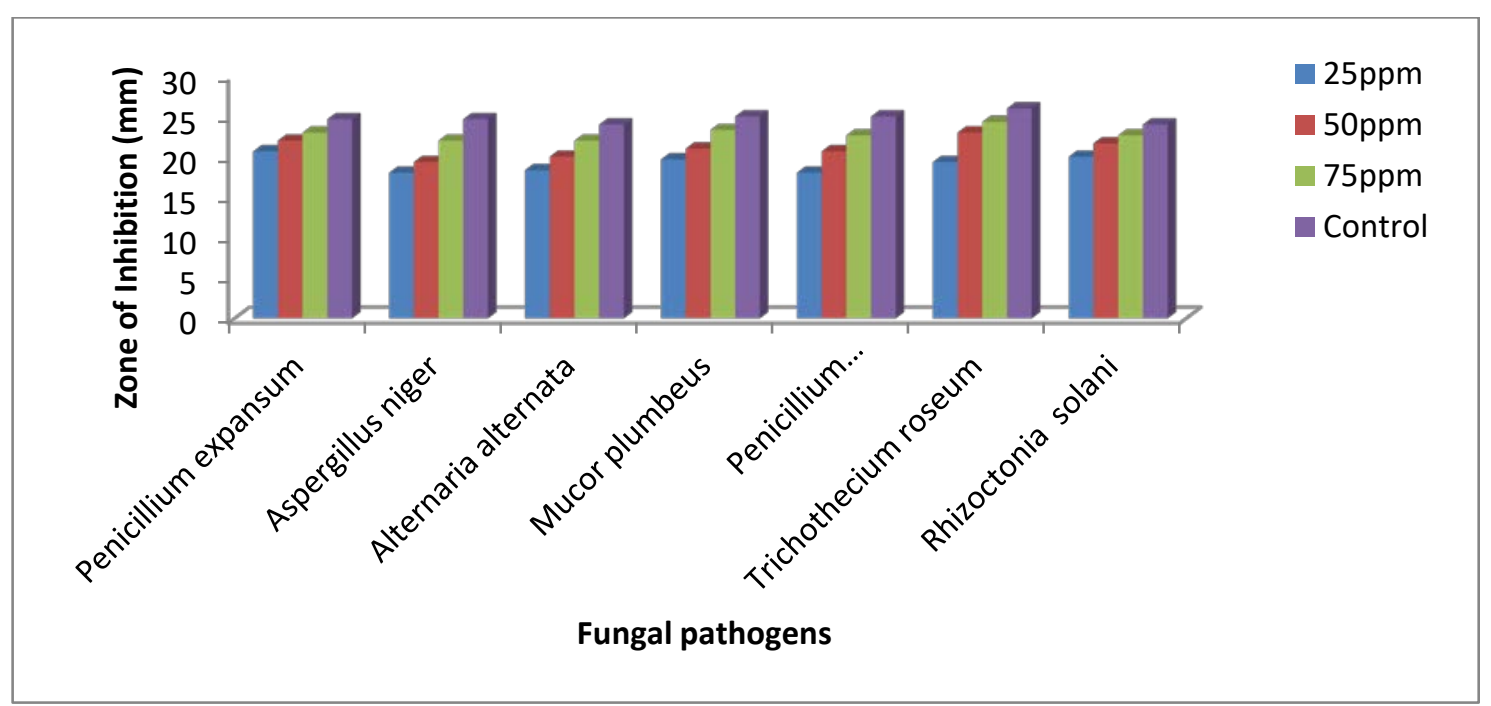

Figure 4. Antifungal activity of aqueous leaf extracts of Iris kashmiriana.

\section{Discussion}

The results clearly indicates that extracts of two medicinal plants Ajuga bracteosa and Iris kashmiriana brought about significant inhibition in the mycelial growth at their different concentration. Higher concentration proved effective than lower concentration. In the present study some plant extracts were evaluated for their antifungal activity against the fungus causing rot of tomato and brinjal. These two test plant species proved highly effective in reducing the mycelial growth of fungi causing rot diseases of tomato and brinjal fruits. Such study has been carried for the first time on the extracts of Ajuga bracteosa and Iris kashmiriana. However, extracts of other plants have been evaluated for their antimycotic activity in a similar way.

In a similar study, Singh et al. (1997) and Kumar et al. (2005) also revealed that fungicides and plant extracts inhibited the mycelial growth of Aspergillus flavus on chilli fruits. Webster et al. (2008) screened 14 plants for their antifungal activity against various pathogenic fungi and concluded that Fragaria virginiana, Epilobium angustifolium and Potentilla simplex show a promising antifungal potential. Gatto et al. (2011) studied the in vitro and in vivo activity of extracts from nine herbaceous species, viz. Borago officinalis, Orobanche crenata, Plantago lanceolata, Plantago coronopus, Sanguisorba minor, Silene vulgaris, Sonchus asper, Sonchus oleraceus and Taraxacum officinale, against some postharvest fungal rot causing pathogens Monilinia laxa, Botrytis cinerea, Penicillium expansum, Penicillium digitatum, Penicillium italicum, Aspergillus carbonarius and Aspergillus niger, and reported that the extract of Sanguisorba minor completely inhibited the spore germination of Monilinia laxa, Penicillium digitatum, Penicillium italicum and Aspergillus niger. TaskeenUn-Nisa et al. (2010) tested plant extracts of three plants, onion (Allium cepa), garlic (Allium sativum) and mint (Mentha arvensis) for their antifungal activity against Alternaria alternata and Rhizopus stolonifer. They observed that the extract of Allium sativum at highest concentration proved highly effective in reducing spore germination of Rhizopus stolonifer and Alternaria alternata followed by extract of Allium cepa and Mentha arvensis. Saheb et al. (2011) reported the antifungal activity of 
various extracts like aqueous, alcoholic and ethyl acetate extracts of leaves of five Terminalia species against five plant pathogenic fungi like Aspergillus flavus, Aspergillus niger, Alternaria brassicicola, Alternaria alternata and Helminthosporium tetramera and found that the ethyl acetate extract showed better inhibitory effect against all the fungi tested. Senguttuvan et al. (2013) reported the antifungal activity of chloroform and methanol extracts of leaf against seven fungi viz. Mucor sp., Trichoderma viride, Verticillium lecanii, Candida albicans, Penicillium sp., $A$. fumigates and $A$. niger and methanol extract showed maximum inhibition in Fusarium sp. Parveen and Wani (2015) reported the inhibitory activity of five plant extracts, viz. Artemisia absinthium, Rumex obtusifolius, Taraxacum officinale, Plantago lanceolata and Malva sylvestris against the mycelial growth of three rot fungi, Alternaria alternata, Penicillium expansum and Mucor piriformis, and observed that all concentrations brought about significant reduction in the mycelial growth of these pathogenic fungi. However, the highest concentration caused maximum inhibition in the mycelial growth. The extract of Artemisia absinthium leaves at highest concentration (S) proved highly effective in inhibiting the mycelial growth of all these pathogenic fungi followed by other plant extracts.

Similarly, other studies also confirmed the effect of different concentration of plant extracts against fungi causing rotting of tomato, brinjal and other fruits (Mangang et al., 2012; Parveen et al., 2014; Tijjani et al., 2014; Koka et al., 2017; Satpute et al., 2017).

\section{Conflict of interest statement}

Authors declare that they have no conflict of interests.

\section{References}

Abril, M.; Curry, K. J.; Smith, B. J.; Wedge, D. E. Improved microassays used to test natural product based and conventional fungicides on plant pathogenic fungi. Plant Disease v. 92, p. 106-112, 2008. http://doi.org/ 10.1094/PDIS-92-1-0106

Ahmad, N.; Amir, M. K.; Ayaz, S.; Ahmad, J. A. Antimicrobial profile of the selected medicinal plants. International Journal of Chemical and Life sciences, v. 2, no. 1, p. 1039-1041, 2012. Available from: <http://www.ijcls.com/index.php/ijcls/articl e/viewFile/40/33>. Accessed on: Nov. 21, 2017.

Alzoreky, N. S.; Nakahara, K. Antibacterial activity of extracts from some edible plants commonly consumed in Asia. International Journal of Food Microbiology, v. 80, no. 3, p. 223-230, 2003. https://doi.org/10.1016/ S0168-1605(02)00169-1

Amin, A.; Wani, S.H.; Mokhdomi, T. A.; Bukhari, S.; Wafai, A. H.; Mir, J. I.; Hassan, Q. P.; Qadri, R. A. Investigating the pharmacological potential of Iris kashmiriana in limiting growth of epithelial tumors. Pharmacognosy Journal, v. 5, no 4, p. $170-175$, 2013. https://doi.org/10.1016/ j.phcgj.2013.07.003

Bhattacharjee, S. K. Handbook of medicinal plants. Jaipur: Pointer Publishers, 1998.

Broekaert, W. F.; Terras, F. R. G.; Cammue, B. P. A.; Vanderleyden, J. An automated quantative assay for fungal growth inhibition. FEMS Microbiology Letters, v. 69, p. 55-60, 1990. https://doi.org/10.1111/j.1574-6968. 1990.tb04174.x

Chandel, S.; Bagai, U. Antiplasmodial activity of Ajuga bracteosa against Plasmodium berghei infected $\mathrm{BALB} / \mathrm{c}$ mice. Indian Journal of Medicinal Research, v. 131, p. 440-444, 2010. Available from: <http://www.ijmr.org.in/temp/IndianJMedR es1313440-5663758_154357.pdf>. Accessed on: Nov. 21, 2017.

Chopra, R. N.; Nayar, S. L.; Chopra, I. C. Glossary of Indian Medicinal Plants. New Delhi: CSIR, 1956.

Dhar, M. L.; Dhawan, B. N.; Mehrotra, B. N.; Ray, C. Screening of Indian plants for 
biological activity: I. Indian Journal of Experimental Biology, v. 6, no. 4, p. 232-247, 1968.

Elgorashi, E. E.; Staden, J. Pharmacological screening of six Amaryllidaceae species. Journal of Ethnopharmacology, v. 90, no. 1, p. 27-32, 2004. https://doi.org/10.1016/ j.jep.2003.09.012

Gatto, M. A.; Ippolito, A.; Linsalata, V.; Cascarano, N. A.; Nigro, F.; Vanadia, S.; Venere, D. D. Activity of extracts from wild edible herbs against postharvest fungal diseases of fruits and vegetables. Postharvest Biology and Technology, v. 61, no. 1, p.72-82, 2011. https://doi.org/ 10.1016/j.postharvbio.2011.02.005

Hanawa, F.; Tahara, S.; Mizutani, J. Isoflavonoids produced by Iris pseudacorus leaves treated with cupric chloride. Phytochemistry, v. 30 , no. 1, p. 157-163, 1991. https://doi.org/10.1016/0031-9422 (91)84117-B

Kayani, W. K.; Dilshad, E.; Ahmed, T.; Ismail, H.; Mirza, B. Evaluation of Ajuga bracteosa for antioxidant, anti-inflammatory, analgesic, antidepressant and anticoagulant activities. BMC Complementary and Alternative Medicine, 16:375, 2016. https://doi.org/ 10.1186/s12906-016-1363-y

Khare, C. P. Indian medicinal plants: An illustrated dictionary. New Delhi: Springer, 2007.

Koka, J. A.; Wani, A. H.; Bhat, M.Y .; Parveen, S. Antifungal activity of ethanolic and aqueous leaf extracts of Taraxicum officinale and Mentha arvensis on the growth of some selected fungal species under in vitro conditions. International Journal of Pure \& Applied Bioscience, v. 5, no. 5, p. 11701176, 2017. https://doi.org/10.18782/23207051.5319

Mahroofa, J.; Seema, S.; Kaloo, Z. A.; Maqbool, F. Medicinal importance of Ajuga bracteosa Wall. ex Benth.: A review. International Journal of Advanced Research, v. 2, no. 1, p. 389-394, 2014. Avilable from: <http://www.journalijar.com/uploads/524_I JAR-2471.pdf>. Accessed on: Nov. 21, 2017.

Mangang, H. C.; Chhetry, G. K. N. Antifungal properties of certain plant extracts against Rhizoctonia solani causing root rot of French bean in organic soil of Manipur. International Journal of Scientific and Research Publications, v. 2, no. 5, p. 1-4, 2012. Available from: <http://www.ijsrp. org/research_paper_may2012/ijsrp-may2012-07.pdf>. Accessed on: Nov. 21, 2017.

Nisar, A.; Akhtar, N.; Hassan, A.; Banday, T.; Wani, B.; Zargar, M.A. Effect of Ajuga bracteosa on systemic T-cell immunity in Balb/C mice: dual Th1/Th2 immunostimulatory effects. The American Journal of Chinese Medicine, v. 42, no. 2, p. 375-392, 2014. https://doi.org/10.1142/ S0192415X14500256

Parveen, S.; Wani, A. H.; Ganie, A. A.; Pala, S. A.; Mir, R. A. Antifungal activity of some plant extracts on some pathogenic fungi. Archives of Phytopathology and Plant Protection, v. 47, p. 279-284, 2014. https://doi.org/10.1080/03235408.2013.80 8857

Parveen, S.; Wani, A. H. In vitro efficacy of some fungicides and plant extracts on Mucor piriformis Fisher causing postharvest rot of peach. Trends in Biosciences, v. 8, no. 3, p. 620-627, 2015.

Parveen, S.; Wani, A. H.; Bhat, M. Y.; Koka, J.A. Biological control of postharvest fungal rots of rosaceous fruits using microbial antagonists and plant extracts: a review. Czech Mycology, v. 68, no. 1, p. 41-66, 2016. Available from: <https://www.czech mycology.org/_cmo/CM68102.pdf>.

Accessed on: Nov. 21, 2017.

Saheb, S. L.; More, S. M.; Junne, S. B.; Wadje, S. S. The antifungal activity of five Terminalia species checked by paper disc method. International Journal of Pharmaceutical Research and Development, v. 3, no. 2, p. 36-40, 2011.

Satpute, S. B.; Vanmare, D. J. In vitro antifungal activity of Tamarindus indica L. extract against pathogenic fungi. International Journal of Botany Studies, v. 2 , no. 3, p. 25-28, 2017. Available from: <http://www.botanyjournals.com/download /114/2-3-16-519.pdf>. Accessed on: Nov. 21, 2017.

Senguttuvan, J.; Paulsamy, S.; Krishnamoorthy, K. In vitro antifungal activity of leaf and root extracts of the medicinal plant, Hypochaeris radicata $\mathrm{L}$. International Journal of Pharmacy and Pharmaceutical Sciences, v. 5, no. 3, p.758-761, 2013. Available from: <http://www.ijppsjournal.com/Vol5Issue3/ 7158.pdf>. Accessed on: Nov. 21, 2017.

Taskeen-un-Nisa; Wani, A. H.; Parveen, S.; Bhat, M. Y. Phytophthora root rot of potato 
and its management in Kashmir Valley. Brazilian Journal of Biological Sciences, $\begin{array}{lll}\text { v. } 4, \quad \text { p. } 7,127-138, & 2017 .\end{array}$ https://doi.org/10.21472/bjbs.040713

Taskeen-Un-Nisa; Wani, A. H.; Mir, R. A. Antimycotic activity of plant extracts on the spore germination of some pathogenic fungi. Mycopath, v. 8, no. 2, p.65-69, 2010. Available from: <http://pu.edu.pk/images/ journal/impp/PDF-FILES/3_Vol_8(2)_ 2010.pdf>. Accessed on: Nov. 21, 2017.

Tijjani, A.; Adebitan, S. A.; Gurama, A. U.; Aliyu, M.; Haruna, S. G.; Mohammad, G. U.; Musab, I. In vitro and in vivo efficacy of some plant extracts for the control of tomato fruit rot caused by Aspergillus flavus. International Journal of Scientific and Research Publications, v. 4, no. 4, p. 1-5, 2014. Available from: <http://www.ijsrp. org/research-paper-0414/ijsrp-p28114.

pdf>. Accessed on: Nov. 21, 2017.

Wani, S. H.; Amin, A.; Rather, M. A.; Parray, J.; Parvaiz, A.; Qadri, R.A. Antibacterial and phytochemical screening of different extracts of five Iris species growing in Kashmir. Journal of Pharmacy Research, v. 5, no. 6, p. 3376-3378, 2012.

Webster, D.; Taschereau, P.; Belland, R. J.; Sand, C.; Rennie, R. P. Antifungal activity of medicinal plant extracts; preliminary screening studies. Journal of Ethnopharmacology, v. 115, p. 140-146, 2008. https://doi.org/10.1016/j.jep.2007. 09.014

License information: This is an open-access article distributed under the terms of the Creative Commons Attribution License, which permits unrestricted use, distribution, and reproduction in any medium, provided the original work is properly cited. 